\title{
Effect of thyroid hormone on mtHsp70 expression, mitochondrial import and processing in cardiac muscle
}

\section{J J Schneider and D A Hood}

Departments of Kinesiology and Health Science and Biology, York University, Toronto, Ontario, Canada, M3J 1P3

(Requests for offprints should be addressed to D A Hood, Department of Biology, York University, 4700 Keele Street, Toronto, Ontario, Canada, M3J 1P3; Email: dhood@yorku.ca)

\begin{abstract}
Mitochondrial heat shock protein 70 (mtHsp70), an important mitochondrial chaperone, is increased in cardiac muscle mitochondria of hyperthyroid rats. To determine the mechanism(s) underlying this increase, we used variations in thyroid status. In Series I, rats were made hyperthyroid by injecting them with 3,3',5-triiodo-Lthyronine $\left(\mathrm{T}_{3}\right)$ for 5 days, or by treating them with vehicle. In Series II, animals were given 6-n-propyl-2thiouracil in their drinking water $(0 \cdot 05 \% \mathrm{w} / \mathrm{v})$ for a period of 32-42 days to make them hypothyroid. During the last 5 days of treatment these animals received injections of either $\mathrm{T}_{3}$ or vehicle. $\mathrm{T}_{3}$ treatment resulted in parallel increases in mtHsp70 protein and mRNA levels in a variety of tissues, suggesting transcriptional regulation.
\end{abstract}

However, evidence of tissue-specific post-transcriptional regulation was also apparent. In isolated heart mitochondria, $\mathrm{T}_{3}$ treatment resulted in a $1 \cdot 8$-fold increase in mtHsp70. This was due to the $1 \cdot 6$-fold greater import of mtHsp70 into mitochondria in $T_{3}$, compared with hypothyroid animals, and it could not be attributed to an altered rate of intramitochondrial $\mathrm{mtHsp} 70$ degradation. The rate of processing of $\mathrm{mtHsp} 70$ to its mature form, reflecting mitochondrial processing peptidase activity, was unaffected by $\mathrm{T}_{3}$, but was more rapid than mtHsp70 import. These data indicate a novel mechanism by which $T_{3}$ modifies the mitochondrial phenotype via the adaptations in the protein import pathway.

Journal of Endocrinology (2000) 165, 9-17

\section{Introduction}

The mitochondrial protein import process is responsible for the recognition of newly synthesized precursor proteins, and the subsequent uptake of those precursors into the organelle. The pathway has been well studied in yeast and fungi (Schatz 1996, Jensen \& Kinnally 1997, Pfanner et al. 1997), and is becoming increasingly well defined in higher animals (Hachiya et al. 1993, Armstrong et al. 1997, Iwahashi et al. 1997). Movement of the precursor protein from the cytosol to the matrix of the mitochondria begins with its recognition by cytosolic chaperones (Komiya et al. 1996). These guide the precursor to the mitochondrion, whereupon they interact with translocases of the outer membrane (Toms). From the outer membrane, the precursor protein moves to the inner membrane, where the presequence interacts with translocases of the inner membrane (Tim proteins). One of these (Tim44) is a peripheral membrane protein bound to the matrix side of the inner mitochondrial membrane. Tim44 serves to anchor the $70 \mathrm{kDa}$ mitochondrial heat shock protein (mtHsp70), which pulls the presequence and the remainder of the protein into the matrix in an energy-dependent manner (Schneider et al. 1994). Subsequently, the presequence is cleaved by a mitochondrial processing peptidase (MPP) yielding a lower molecular weight, mature protein.

$\mathrm{mtHsp70}$ is essential for cell viability in yeast, and it has been suggested that it may play a regulatory role in the import of matrix-destined precursor proteins (Dekker et al. 1997). Evidence that mtHsp70 is critically important in the protein import process is also suggested by its marked inducibility under conditions of chronic contractile activity in skeletal muscle (Ornatsky et al. 1995, Takahashi et al. 1998), and as a result of thyroid hormone treatment in cardiac muscle mitochondria (Craig et al. 1998), conditions in which mitochondrial biogenesis is enhanced. The increase in $\mathrm{mtHsp} 70$ concentration in mitochondria under those conditions could be due either to an increased import, or a decreased degradation of the protein within the matrix. While the role of $\mathrm{mtHsp} 70$ in lower eukaryotic cells is becoming well defined, its expression, import into mitochondria, processing and degradation in mammalian cells has never been evaluated. Furthermore, analysis of all of these important steps, which in general determine mitochondrial phenotypic adaptations, has not been performed in a tissue undergoing mitochondrial biogenesis. Thus, by using thyroid hormone $\left(\mathrm{T}_{3} ; 3,3^{\prime}, 5\right.$-triiodoL-thyronine) as an inducer of mitochondrial biogenesis, we examined the pathway of gene expression of the 
mitochondrial chaperone mtHsp70, and we have identified the protein import step as one which is adaptable under conditions of $\mathrm{T}_{3}$-induced organelle synthesis.

\section{Materials and Methods}

In this study we sought to examine the expression pathway of a single protein ( $\mathrm{mtHsp} 70)$ starting from its mRNA expression to its final destination within the organelle, in an attempt to identify some potential sites of regulation during mitochondrial biogenesis. In order to visualize the effect of $\mathrm{T}_{3}$ most dramatically, two series of experiments were performed. In the first Series, normal animals were administered $T_{3}$ at a dose sufficient to make them hyperthyroid, as done previously (Paradies et al. 1994, Craig et al. 1998). In the second Series, animals were first made hypothyroid with 6-n-propyl-2-thiouracil (PTU) treatment for $>30$ days, after which they were injected with $\mathrm{T}_{3}$ as in Series I.

\section{Animal care and treatments}

Male Sprague-Dawley rats $(n=66,200-350 \mathrm{~g})$ were housed individually with a ratio of $12 \mathrm{~h}$ light: $12 \mathrm{~h}$ darkness cycle. Food and water were given ad libitum. All procedures involving animals were approved by the York University Animal Care Committee, in accordance with the Canadian Council on Animal Care.

\section{Series $I: T_{3}$ treatment}

$\mathrm{T}_{3}$ was dissolved in vehicle (100\% propylene glycol:0.9\% $\mathrm{NaCl}(1 \cdot 5: 1, \mathrm{v}: \mathrm{v}))$ to a final concentration of $0 \cdot 4 \mathrm{mg} / \mathrm{ml}$. Animals were injected with $T_{3}$ (i.p. $0 \cdot 4 \mathrm{mg} / \mathrm{kg}$ ) once per day for 5 days. Control animals were administered vehicle in the same manner and at the same time as $T_{3}$-injected animals. Twenty-four hours following the fifth injection, they were anesthetized with sodium pentobarbitol $(60 \mathrm{mg} / \mathrm{kg}$, i.p) and selected hindlimb muscles (soleus, red gastrocnemius (RG), white gastrocnemius (WG)) and liver were removed, quick frozen and stored in liquid $\mathrm{N}_{2}$ for the subsequent assessment of tissue mtHsp70 mRNA and protein levels. Animals were killed by the removal of the heart for mitochondrial isolation.

\section{Series II: PTU administration followed by $T_{3}$ treatment}

6-n-propyl-2-thiouracil (PTU) was dissolved in the drinking water to a concentration of $0 \cdot 05 \%(\mathrm{w}: \mathrm{v})$. Rats were administered PTU for a period of 32-42 days. During the last 5 days of treatment, animals received injections of either $\mathrm{T}_{3}$ or vehicle as described above. Twenty-four hours later they were anesthetized and the tissues were removed as described above.

\section{Cardiac mitochondrial isolation}

The heart was removed from the chest cavity and placed on ice. Approximately $50 \mathrm{mg}$ of the left ventricle was quick frozen and stored in liquid $\mathrm{N}_{2}$ for the assessment of mtHsp70 mRNA and protein levels. The remaining heart tissue was used in the mitochondrial isolation procedure, as described previously (Craig et al. 1998). Mitochondrial protein was assessed (Bradford 1976) and the concentration was adjusted to $1 \mathrm{mg} / \mathrm{ml}$.

In vitro transcription, translation and import of $m t H s p 70$

The full-length cDNA clone for human mtHsp70 (Bhattacharyya et al. 1995) was a gift from Dr Richard Morimoto (Northwestern University, Evanston, IL, USA). The cDNA was linearized using Bam H1 and subsequently phenol extracted and ethanol precipitated. MtHsp70 was in vitro transcribed with T7 RNA polymerase, followed by in vitro translation in the presence of ${ }^{35} \mathrm{~S}$-methionine and rabbit reticulocyte lysate, as described previously (Takahashi \& Hood 1996, Craig \& Hood 1997). Mitochondria were pre-incubated for $5 \mathrm{~min}$ at $30{ }^{\circ} \mathrm{C}$ prior to the import assay. Translation mix $(10 \mu \mathrm{l}$ per $25 \mu \mathrm{g}$ of mitochondrial protein) was added and the import incubation was allowed to proceed at $30^{\circ} \mathrm{C}$ for $5,10,15$ or $20 \mathrm{~min}$. Import was halted by adding an aliquot of the mitochondria-translation mix to an ice-cold sucrose cushion $(600 \mathrm{mM}$ sucrose, $100 \mathrm{mM} \mathrm{KCl}, 20 \mathrm{mM}$ HEPES, $2 \mathrm{mM} \mathrm{MgCl} 2$ ). Mitochondria were pelleted for $15 \mathrm{~min}$ at $18000 \mathrm{~g}\left(4{ }^{\circ} \mathrm{C}\right)$ and resuspended in $25 \mu \mathrm{l}$ of ice-cold breaking buffer $(600 \mathrm{mM}$ sorbitol, $20 \mathrm{mM}$ HEPES, $\mathrm{pH}$ $7 \cdot 4$ ), denatured with $\beta$-mercaptoethanol at $95^{\circ} \mathrm{C}$ for 5 min, quick cooled on ice and then electophoresed through an 8\% SDS-polyacrylamide gel. Gels were processed and dried as described previously (Takahashi \& Hood 1996, Craig \& Hood 1997). Images and subsequent quantification were obtained with electronic autoradiography (Instantimager, Packard, Meriden, CT, USA). Imported, mature $\mathrm{mtHsp} 70$ was distinguished from precursor mtHsp70 because of its lower molecular weight. The percentage of available protein that was imported was calculated based on the intensity of a lane containing $4 \mu \mathrm{l}$ of translation mixture in the absence of mitochondria.

\section{Degradation of $m t H s p 70$}

Mitochondria were pre-incubated for $5 \mathrm{~min}$ at $30{ }^{\circ} \mathrm{C}$. Translation mix (10 $\mu \mathrm{l}$ per $25 \mu \mathrm{g}$ of mitochondrial protein) was added, and the import incubation was allowed to proceed at $30{ }^{\circ} \mathrm{C}$ for $20 \mathrm{~min}$. Import was halted by placing the mitochondria-translation mixture on ice, followed by the addition of valinomycin to a concentration of $0.5 \mu \mathrm{M}$. Preliminary experiments verified that this concentration of valinomycin was effective in inhibiting any further import of external precursor protein. After $5 \mathrm{~min}$ on ice, samples were placed at $30^{\circ} \mathrm{C}$. Aliquots corresponding to $25 \mu \mathrm{g}$ of mitochondrial protein were removed after $0,0 \cdot 5,1,1 \cdot 5$, and $2 \mathrm{~h}$ and placed on ice-cold sucrose cushions and samples were processed as described in the import assay. 


\section{MPP activity}

Mitochondria previously stored at $-20{ }^{\circ} \mathrm{C}$ were thawed at $4{ }^{\circ} \mathrm{C}$. Protease inhibitors were added to final concentrations of $2 \mu \mathrm{g} / \mathrm{ml}$ leupeptin, $2 \mu \mathrm{g} / \mathrm{ml}$ pepstatin $\mathrm{A}$ and $0.1 \mathrm{mM}$ phenylmethylsuphonyl fluoride. Extracts were prepared by subjecting the mitochondria to 3 freeze/thaw cycles, alternating between liquid nitrogen and $30{ }^{\circ} \mathrm{C}$. $\mathrm{MnCl}_{2}$ was added to a final concentration of $0.5 \mathrm{mM}$. To measure MPP activity, the extracts were preincubated at $30{ }^{\circ} \mathrm{C}$. Translation mix containing in vitro translated mtHsp70 (4 $4 \mathrm{l})$ was added to $25 \mu \mathrm{g}$ of mitochondrial extract. Aliquots were removed at $0,1,2,3,5$, and $10 \mathrm{~min}$ and placed onto ice-cold lysis buffer containing 5\% $\beta$-mercaptoethanol. Samples were denatured and run on an $8 \%$ polyacrylamide gel as described above. The intensity of both the precursor and mature bands was quantified using electronic autoradiography, and MPP activity was expressed as the ratio of the intensity of mature band to the sum of the mature plus precursor band.

\section{RNA measurements}

Total RNA was isolated from tissue powders and quantified as described previously (Connor et al. 1996). Total RNA (10 $\mu$ g per slot) was transferred onto a nitrocellulose membrane using a slot blot apparatus, as done previously (Hood 1990, Hood et al. 1992). RNA was fixed onto the membrane using UV light. The membrane was then hybridized with a random primer ${ }^{32} \mathrm{P}-$ labeled $300 \mathrm{bp}$ fragment of the mtHsp70 coding region obtained from the mtHsp70 cDNA cut with EcoRI. The intensity of the autoradiographic signal was used as the measure of mtHsp70 mRNA level. Variations in loading were corrected using the subsequent hybridization of a radiolabeled $18 \mathrm{~S}$ rRNA probe (Takahashi et al. 1998).

\section{Immunoblotting}

Total tissue proteins were extracted from frozen powders as described previously (Takahashi et al. 1998). Mitochondrial proteins or total tissue proteins were then electrophoresed through a 10\% SDS-polyacrylamide gel and transferred to a nitrocellulose membrane (Hybond-C, Amersham Pharmacia Biotech, Baie d'Urfé, Québec, Canada). This membrane was subsequently probed with a monoclonal antibody (diluted 1:1000) directed against mtHsp70 (Stress-Gen Biotechnologies, Victoria, Canada). The secondary antibody used for detection of the final staining reaction was a goat anti-mouse $\operatorname{IgG}$ conjugated to alkaline phosphatase. Quantification of the colour intensity was obtained using laser densitometry (Ornatsky et al. 1995).

\section{Statistics}

Independent $t$-tests were employed for the comparison of mRNA and protein levels of mtHsp70 with $\mathrm{T}_{3}$ treatment
(Series I). Two-way analyses of variance with repeated measures on one factor (time) were used for import, degradation, and MPP activity data. A Tukey post hoc comparison was employed in the analysis of the import ANOVA. Data within the text and on all graphs are expressed as means \pm s.E.M.

\section{Results}

\section{Cardiac hypertrophy}

In Series I, the heart to body weight ratio was $3.42 \pm 0.05 \mathrm{mg} / \mathrm{g}$ for $\mathrm{T}_{3}$-treated rats and $2 \cdot 46 \pm 0.04 \mathrm{mg} /$ $\mathrm{g}$ for vehicle-treated animals. Thus, $\mathrm{T}_{3}$ treatment resulted in a $39 \%$ increase in heart weight $(n=16)$. Similarly, in Series II, $\mathrm{T}_{3}$ treatment following PTU administration resulted in a $42 \%$ increase in heart weight $(n=9)$. The animals administered $\mathrm{T}_{3}$ had a heart to body weight ratio of $3.21 \pm 0.09 \mathrm{mg} / \mathrm{g}$ while the corresponding ratio for vehicle-treated animals was $2.27 \pm 0.03 \mathrm{mg} / \mathrm{g}$. Thus, the PTU treatment resulted in an $8 \%$ cardiac atrophy relative to vehicle control animals.

\section{Expression of $m t H s p 70$}

Initially, we characterized the protein and mRNA expression of $\mathrm{mtHsp} 70$ in five different tissues which differ widely in mitochondrial content, as done previously (Hood 1990, Ornatsky et al. 1995). For Series I vehicle animals, slot blot analyses indicated that the highest level of mtHsp70 mRNA was found in heart, followed by RG, liver, soleus, and WG (Fig. 1A). The WG possessed mRNA values which were $3 \cdot 5$-fold lower than in heart. $\mathrm{T}_{3}$ induced an increase in $\mathrm{mtHsp} 70$ mRNA by $49 \%$ in liver, $22 \%$ in heart, $40 \%$ in soleus and $85 \%$ in WG $(P<0 \cdot 05)$ in Series I animals. Immunoblot analyses of these same tissues indicated comparable levels of $\mathrm{mtHsp} 70$ protein in heart and liver. These were approximately 4-fold higher than those in the soleus and the RG, and 20 -fold greater than in the WG. The induction of $\mathrm{mtHsp} 70$ protein levels by $\mathrm{T}_{3}$ was particularly marked in liver and soleus, in which $61 \%$ and $82 \%$ increases were observed (Fig. 1B). In Series II, PTU treatment (reflecting the hypothyroid state) resulted in decreased $(P<0.05)$ mRNA levels in heart, but not other tissues, when compared with vehicle treatment alone. $\mathrm{T}_{3}$ induced a greater increase in $\mathrm{mtHsp} 70 \mathrm{mRNA}$ than in Series I, by $69 \%$ in liver, $47 \%$ in heart, $71 \%$ in soleus, $52 \%$ in RG and $169 \%$ in WG $(P<0 \cdot 05)$. At the protein level, PTU treatment resulted in a more widespread decrease in mtHsp70 level compared with vehicle-treated, euthyroid animals. $\mathrm{T}_{3}$ also resulted in elevations $(P<0 \cdot 05)$ of $\mathrm{mtHsp} 70$ protein in liver $(2 \cdot 3$-fold $)$, soleus $(14 \cdot 2$-fold $)$ and RG (3.2-fold). These increases were greater than those observed in Series I. 

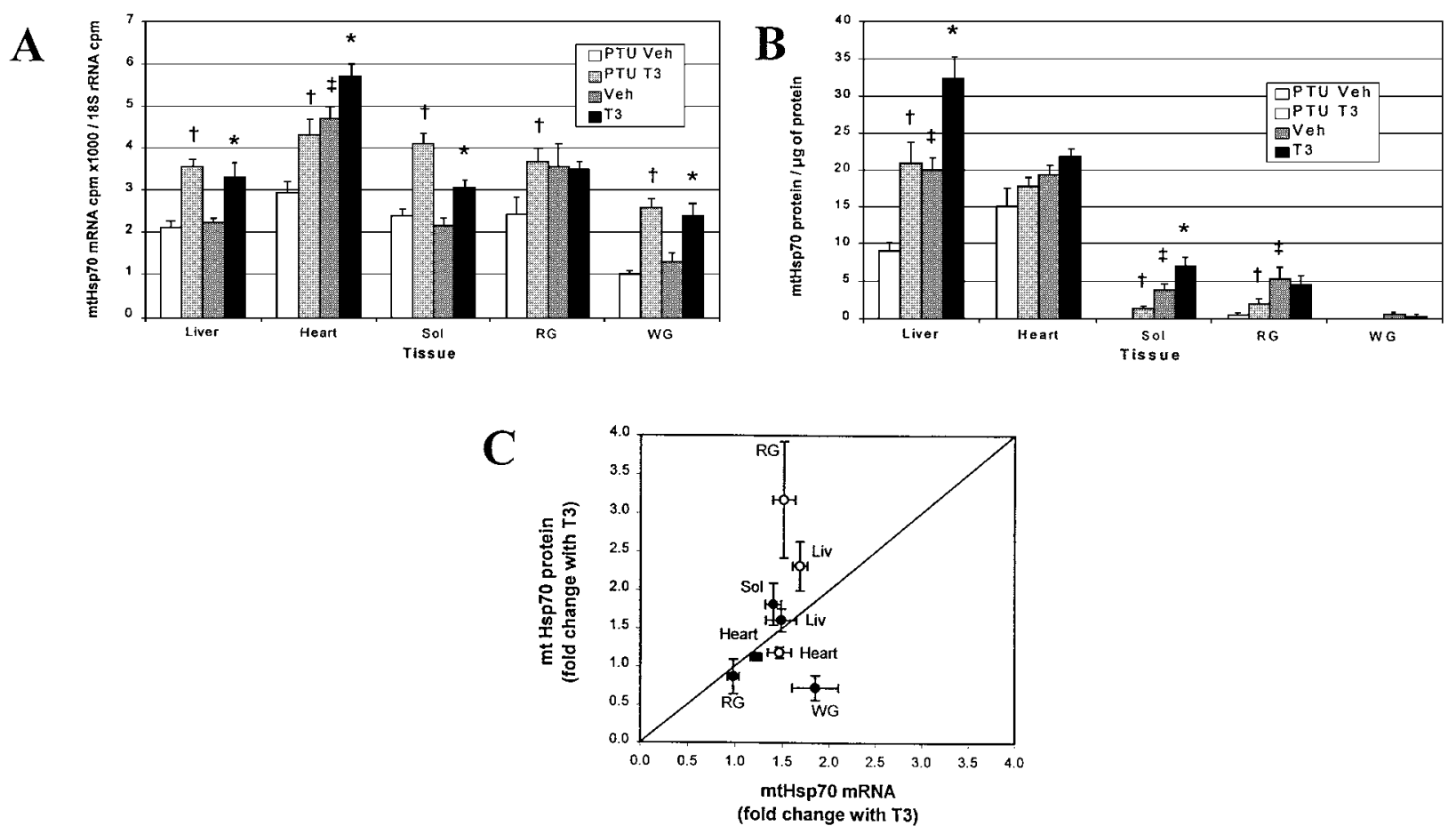

Figure 1 Expression of mtHsp70 mRNA and protein in five tissues. (A) Slot blot analyses (12 $\mu \mathrm{g}$ of total RNA per slot) were used to quantify the relative levels of mtHsp70 mRNA between tissues and with thyroid hormone treatment. 18S rRNA was used to correct for differences in loading ( $n=4-8$ animals/tissue). (B) Immunoblots were used to quantify the relative levels of mtHsp70 protein and the effect of $\mathrm{T}_{3}$ ( $n=6$ animals/tissue), ( ${ }^{*} P<0 \cdot 05$ between vehicle and $\mathrm{T}_{3},+P<0 \cdot 05$ between PTU vehicle and PTU $\mathrm{T}_{3}, \ddagger P<0 \cdot 05$ between vehicle and PTU vehicle). (C) Comparison of the fold change in mRNA and protein in response to $T_{3}$ treatment. Values are re-expressed from the data shown in Figs 1A and B. The solid line indicates the line of identity, where the fold increase in mtHsp70 mRNA is equal to the fold increase in $\mathrm{mtHsp70}$ protein. - Series I animals, $\bigcirc$ Series II animals; Liv, liver; Sol, soleus muscle; RG, red gastrocnemius muscle; WG, white gastrocnemius muscle. In Series II, WG mtHsp70 protein levels were not detectable, while mRNA levels were induced 2.7-fold. Soleus values were $1 \cdot 7$-fold (mRNA) and $14 \cdot 2$-fold (protein). These data for soleus and WG are not illustrated. All data points are expressed as means \pm S.E.M.

In general, a close parallel (Fig. 1C) existed between the $\mathrm{T}_{3}$-induced increases in protein and mRNA levels of Series I tissues. The sole exception was WG. In this tissue, and in Series II tissues (soleus and RG), the change in mRNA concentration was not accompanied by an equivalent change at the protein level, suggesting some posttranscriptional regulation of $\mathrm{mtHsp} 70$ expression under these conditions.

The increase in $\mathrm{mtHsp} 70$ protein evident in heart tissue was localized to the mitochondria. $\mathrm{T}_{3}$ induced a $1 \cdot 8$-fold $(n=16, P<0 \cdot 05)$ increase in $\mathrm{mtHsp} 70$ in isolated cardiac mitochondria (Fig. 2).

\section{Import of mtHsp 70 into isolated cardiac mitochondria}

To evaluate the effect of $\mathrm{T}_{3}$ on $\mathrm{mtHsp} 70$ import, in vitro translated mtHsp70 was incubated with mitochondria isolated from hearts obtained from animals in Series I and II (Fig. 3). A typical import time course autoradiogram is shown in Fig. 3A. The human $\mathrm{mtHsp} 70$ protein used in this study was rapidly imported and processed by rat heart mitochondria. This was expected based on evidence that the activity of the protein import machinery is not species-specific (Craig et al. 1998, Takahashi et al. 1998). Quantification of import reactions derived from several experiments (Fig. 3B) indicates that the import of $\mathrm{mtHsp} 70$ proceeded linearly over time. Import was significantly lower in animals administered PTU+vehicle $(P<0 \cdot 05)$. Compared with this PTU-vehicle group, import was $60 \%$ higher in PTU $+\mathrm{T}_{3}$-treated animals, $60 \%$ higher in vehicle-treated animals, and $90 \%$ higher in $\mathrm{T}_{3}$-treated animals when all incubation time points were considered. In addition, the rate of increase in $\mathrm{mtHsp70}$

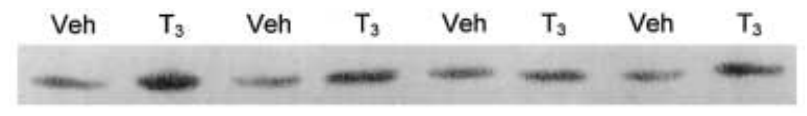

Figure 2 A typical immunoblot illustrating mtHsp70 levels in isolated cardiac mitochondria from four vehicle- (Veh) and four thyroid hormone- $\left(\mathrm{T}_{3}\right)$ treated rats $(25 \mu \mathrm{g}$ of mitochondrial protein applied per lane). 
A

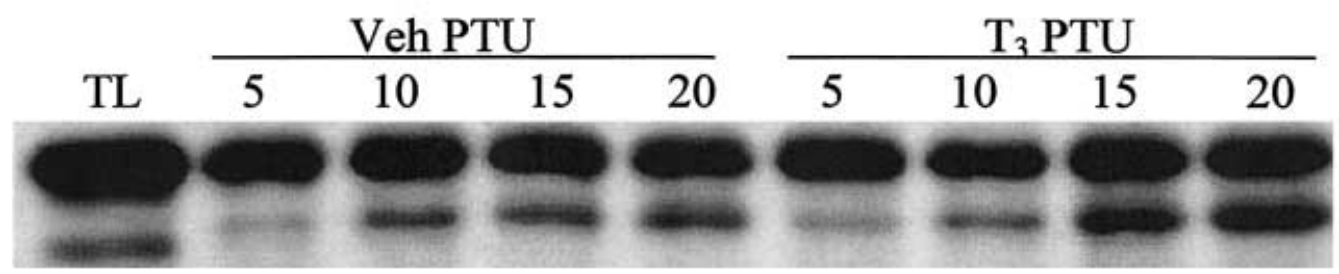

B

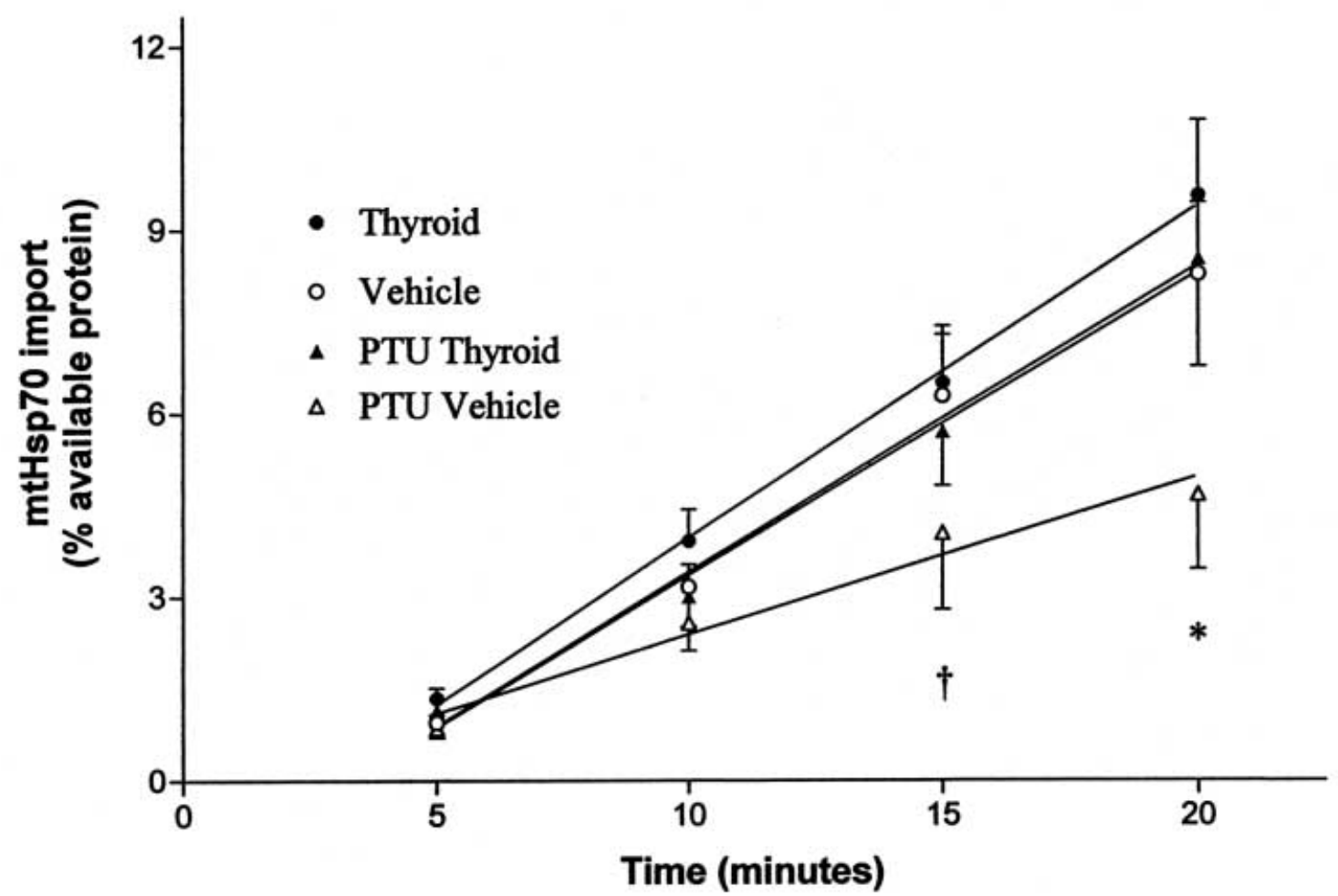

Figure 3 Import of $\mathrm{mtHsp} 70$ into isolated cardiac mitochondria. (A) Autoradiograph of a representative reaction comparing import of $\mathrm{mtHsp70}$ in mitochondria obtained from vehicle-treated PTU rats (Veh PTU) and from thyroid-treated PTU rats ( $\mathrm{T}_{3}$ PTU) at 5, 10, 15, and 20 min of import (TL, translation lane, where $4 \mu$ l of translation product was loaded). The lower band represents the imported $\mathrm{mtHsp70}$. (B) Quantification of the autoradiograph from multiple experiments $(n=15$ animals for vehicle and thyroid values, $n=9$ animals for vehicle PTU and thyroid PTU values). A two-way ANOVA revealed a significant effect of treatment between the vehicle PTU and thyroid PTU group $(P<0 \cdot 05)$. Post hoc comparisons demonstrated that the vehicle PTU group was different from all groups after $20 \mathrm{~min}\left(^{*}\right)$ and different from thyroid and vehicle groups after 15 min (†). All data points are expressed as means \pm S.E.M.

import was significantly lower in PTU-vehicle animals than in any of the other groups $(P<0 \cdot 05)$. Compared with the PTU-vehicle group, the rate of import was $126 \%$ higher in $\mathrm{PTU}+\mathrm{T}_{3}$ animals, $130 \%$ higher in vehicletreated animals, and $150 \%$ higher in $\mathrm{T}_{3}$-treated animals. Thus, the administration of $\mathrm{T}_{3}$ to PTU-treated animals normalized the rate of import to that found in non-PTU vehicle animals.

\section{MPP activity}

To assess the potential effect of $\mathrm{T}_{3}$ on the processing of mtHsp70, the activity of the mitochondrial processing peptidase was measured. In establishing the assay conditions, preliminary experiments indicated that MPP activity was sensitive to the presence of metal cations (e.g. $\mathrm{Mn}^{2+}$ ), and that it could be inhibited by pre-incubation 
A
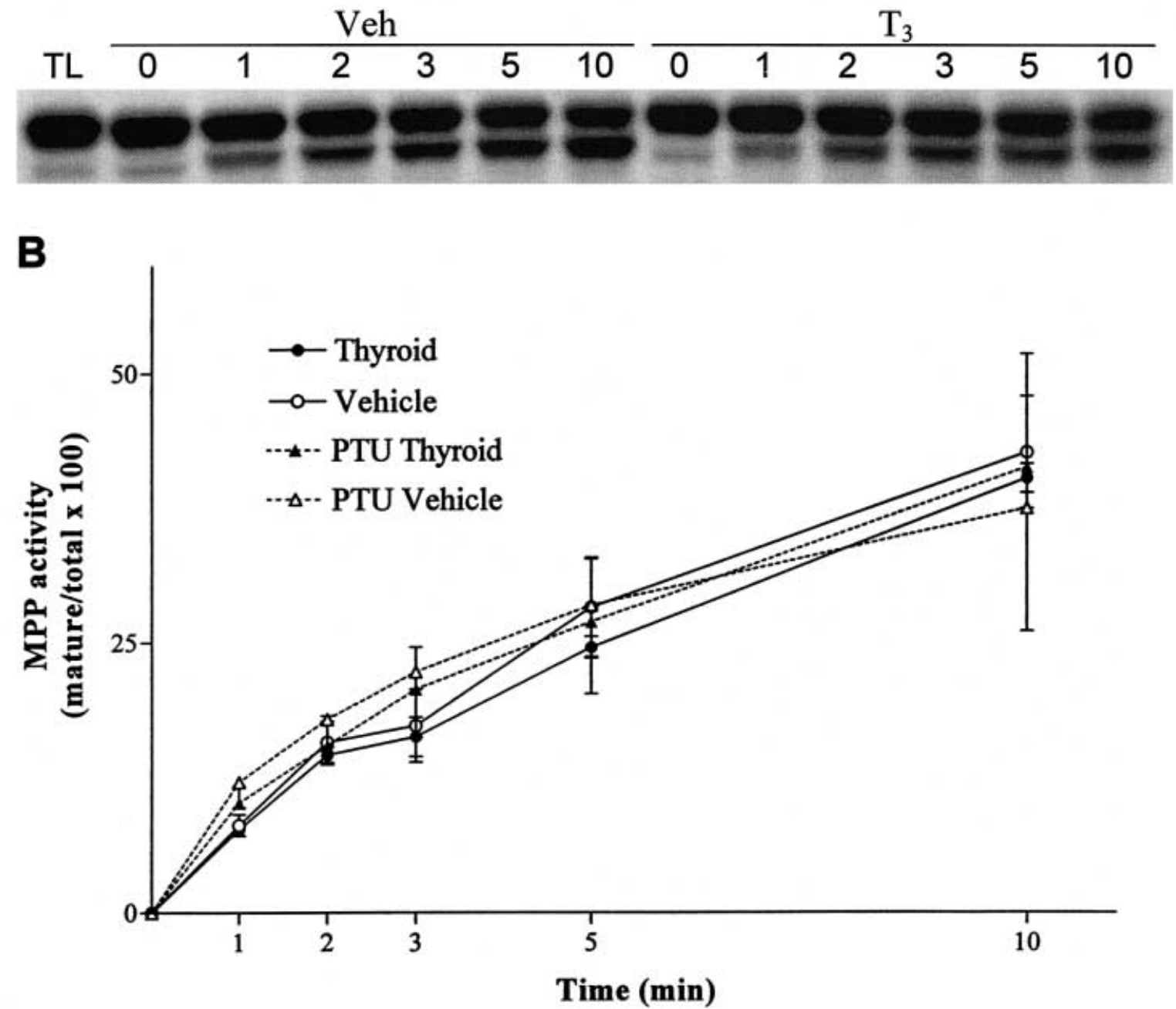

Figure 4 In vitro assay of MPP activity. (A) Autoradiograph of typical MPP assay. Mitochondrial extracts were prepared from isolated cardiac mitochondria (Veh, vehicle treated rats; $T_{3}$, thyroid hormone treated rats; $T L$, translation lane) and incubated with in vitro radiolabeled $\mathrm{mtHsp70}$ for the times $(\mathrm{min})$ indicated. (B) Quantification of autoradiographs from multiple experiments. Vehicle and $T_{3}$ values are shown, as are vehicle PTU and $T_{3}$ PTU values. All data points are expressed as means \pm S.E.M. $(n=4$ animals/treatment). There were no significant differences between groups.

with o-phenanthroline, the metal ion chelator, as previously reported (Peralta et al. 1993). No effect of $\mathrm{T}_{3}$ was evident on MPP activity (Fig. 4). MPP activity was much more rapid than import, since detectable processing of $\mathrm{mtHsp} 70$ to its mature form was evident as early as $1 \mathrm{~min}$ post-incubation. The amount of the signal represented by the mature form of $\mathrm{mtHsp} 70$ was approximately $10 \%$ by 1 min in MPP assays (average for all groups). In contrast, this level of conversion to mature $\mathrm{mtHsp} 70$ was only achieved after 20 min during protein import measurements.

\section{Degradation}

Since the $\mathrm{T}_{3}$-induced increase in the levels of mtHsp70 in cardiac mitochondria could possibly be attributed to a reduction in $\mathrm{mtHsp} 70$ degradation, we assessed the intra-mitochondrial proteolysis of $\mathrm{mtHsp} 70$ in vehicle and $T_{3}$-treated animals. $T_{3}$ treatment had no effect on the degradation rate of $\mathrm{mtHsp} 70$ as measured over a 2-h period (Fig. 5), indicating the relative stability of the protein following import into mitochondria. 


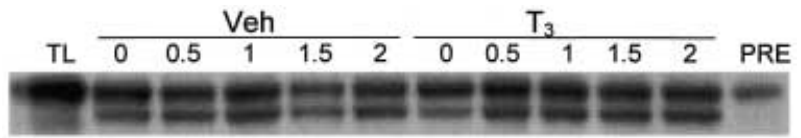

Figure 5 Degradation of $\mathrm{mtHsp} 70$ in isolated cardiac mitochondria. Autoradiograph of a typical degradation assay comparing the level of $\mathrm{mtHsp70}$ in mitochondria following import in vehicle (Veh) versus thyroid hormone $\left(\mathrm{T}_{3}\right)$ treated animals. Levels were measured at $t=0$ (termination of import), $0.5,1,1 \cdot 5$, and $2 \mathrm{~h}$. PRE indicates mitochondria which were pre-incubated with valinomycin prior to import and degradation. Replication of multiple identical experiments ( $n=9$ animals/treatment) did not reveal any effect of $\mathrm{T}_{3}$ on the degradation of $\mathrm{mtHsp} 70$ (results not shown).

\section{Discussion}

In response to whole body $\mathrm{T}_{3}$ treatment, the heart hypertrophies. This is a result of marked alterations in the expression of contractile protein genes, accompanied by changes in the sarcoplasmic reticulum and mitochondria (Glass \& Holloway 1990). It is well established that $T_{3}$ is a physiologically relevant inducer of mitochondrial biogenesis in cardiac muscle, eliciting changes in mitochondrial content and composition (Nishiki et al. 1978, Soboll 1993) which appear to parallel cell growth. Many of these effects are exerted at the level of transcription of nuclear-encoded mitochondrial genes (Nelson et al. 1995), but evidence for post-transcriptional regulation also exists (Hood et al. 1992). The results indicate that mtHsp70 protein concentration was lowest after PTU treatment alone, and highest in normal animals receiving $\mathrm{T}_{3}$. This effect of $\mathrm{T}_{3}$ on $\mathrm{mtHsp} 70$ was localized to mitochondria, and was due largely to an acceleration of precursor protein import kinetics. This acceleration of $\mathrm{mtHsp} 70$ import could not be associated with changes in processing, since MPP activity was much more rapid than import, and was not inducible by $\mathrm{T}_{3}$.

We chose mtHsp70 for this study because it is a critical protein involved in the import (Kang et al. 1990), unfolding (Matouschek et al. 1997), refolding (Stuart et al. 1994), and degradation (Wagner et al. 1994) of precursor proteins. Although $\mathrm{mtHsp} 70$ has a role in both import and proteolysis, the $\mathrm{T}_{3}$-induced increase in $\mathrm{mtHsp} 70$ within mitochondria was accompanied only by changes in import. This lack of effect of $T_{3}$ on intramitochondrial proteolysis was also found using a mutant form of cytochrome b2, which is misfolded and missorted to the matrix (Craig et al. 1998). These results were surprising in view of the role of mtHsp70 in facilitating the action of the matrix protease PIM1 (Wagner et al. 1994). Thus, it may be that mtHsp70 is found at sufficiently high levels within the mitochondria under normal conditions to support its role in the degradation of intramitochondrial proteins. Alternatively, mtHsp70 may only recognize proteins other than itself when directing proteins to the proteolytic pathway. In any event, the increase in $\mathrm{mtHsp} 70$ concentration within cardiac mitochondria as a result of $\mathrm{T}_{3}$ treatment appears to be due to an increase in import, in the absence of changes in degradation.

It is interesting to speculate that the effect of a $\mathrm{T}_{3}$ induced enhancement of $\mathrm{mtHsp} 70$ import might serve to accelerate the import of other matrix-destined proteins, as well as itself, in a positive-feedback fashion. It has been suggested that $\mathrm{mtHsp} 70$ is an important regulatory protein within the import machinery (Dekker et al. 1997). However, evidence for mtHsp70's involvement as a ratelimiting step in the import process has yet to be determined, and will probably involve the selective over- or underexpression of $\mathrm{mtHsp} 70$ using gene-targeting techniques, along with coincident measures of protein import. We have recently shown that $T_{3}$ increases the level of the outer membrane import receptor Tom 20 in cardiac muscle mitochondria (Craig et al. 1998), as well as in C2C12 muscle cells (JY Grey, MK Connor, JW Gordon \& DA Hood, unpublished observations). Using coincident measures of protein import in intact cells, we found that changes in Tom20 levels, mediated either by $\mathrm{T}_{3}$, forced overexpression via a Tom20 expression construct, or reduced expression using antisense oligonucleotides, led to parallel alterations in the import of proteins into the matrix space. This provides strong evidence that the mechanism of action of $\mathrm{T}_{3}$ on the import process is, in part, exerted via changes in the expression of components of the outer membrane import receptor complex. It is also of interest to note that changes in protein import mediated by $\mathrm{T}_{3}$, as observed using isolated mitochondria in the present study, are also reflected in studies using intact cells (JY Grey, MK Connor, JW Gordon \& DA Hood, unpublished observations). However, it should be noted that in cells, import of radiolabeled precursor protein is expected to be a function of: (1) the concentration of the precursor, which may exist in the cytosol at or below the $\mathrm{K}_{\mathrm{m}}$ value for transport, and (2) the capacity of the protein import machinery for transport, determined by the concentration of Tom and Tim proteins in the membrane. Thus, a discordance between observations made in vitro and those using intact cells is possible, since import into isolated mitochondria using a precursor protein synthesized in a reticulocyte lysate system is designed to be independent of precursor protein concentration.

Finally, in light of evidence showing that $\mathrm{mtHsp} 70$ is inducible with $\mathrm{T}_{3}$ treatment, it was of interest to study the regulatory events governing this increased expression. Using tissues possessing a wide range of mitochondrial contents (Hood 1990) and hence varying amounts of mtHsp70, it is evident from the data in Series I that the increase in $\mathrm{mtHsp} 70$ protein was largely accompanied by increases in mtHsp70 mRNA (Fig. 1C). These data provide an indirect indication that the predominant form of regulation is transcriptional in nature. Sequences with a close similarity $(83 \%)$ to the concensus thyroid response element half-site consisting of AGGTCA are found 
upstream of the murine mtHsp70 gene (Michikawa et al. 1993). Assuming that the currently unknown promoter sequence in the rat is similar, this lends support to the idea that the effect of $\mathrm{T}_{3}$ on $\mathrm{mtHsp} 70$ expression is mediated, at least in part, via increases in transcription. However, an exception to this may be found in the WG, a tissue with a very low mitochondrial concentration as well as a low expression of $\mathrm{T}_{3}$ receptors, typical of fast-twitch muscle types (Schuler \& Pette 1998). In this case, the increase in mtHsp70 mRNA was not accompanied by an increase at the protein level, suggesting either a $\mathrm{T}_{3}$-induced acceleration of $\mathrm{mtHsp} 70$ degradation, or a reduced translation of the transcript. Interestingly, a very different pattern of change in mtHsp70 mRNA and protein expression was observed in animals previously treated with PTU to reduce endogenous $T_{3}$ levels, followed by $T_{3}$ administration (Series II). In this situation, the effect of $\mathrm{T}_{3}$ appeared to more dramatically alter the balance between transcriptional and post-transcriptional regulation in a tissue-specific fashion. This is illustrated most effectively by the comparison of soleus and RG muscles between Series I and Series II (Fig. 1C). Further studies incorporating the direct measurement of mtHsp70 transcription using nuclear run-on assays, combined with measures of protein turnover rates under the influence of $\mathrm{T}_{3}$ will be necessary to identify the mechanism involved and improve our understanding of the regulation of $\mathrm{mtHsp} 70$ expression in these tissues.

\section{Acknowledgements}

The cDNA encoding mtHsp70 was kindly provided by Dr Richard Morimoto, Northwestern University, Evanston, Illinois, USA. The authors thank Mike Connor and Elaine Craig for their expert advice during the course of this study, and Dahlia Jarczyn for her expert technical assistance. This work was supported by a grant from the Heart and Stroke Foundation of Canada to DA Hood.

\section{References}

Armstrong LC, Komiya T, Bergman BE, Mihara K \& Bornstein P 1997 Metaxin is a component of a preprotein import complex in the outer membrane of the mammalian mitochondria. Journal of Biological Chemistry 272 6510-6518.

Bhattacharyya T, Karnezis AN, Murphy SP, Hoang T, Freeman BC, Phillips B \& Morimoto RI 1995 Cloning \& subcellular localization of human mitochondrial Hsp70. Journal of Biological Chemistry 270 1705-1710.

Bradford MM 1976 A rapid and sensitive method for the quantitation of microgram quantities of protein utilizing the principle of protein-dye binding. Analytical Biochemistry 72 248-254.

Connor MK, Takahashi M \& Hood DA 1996 Tissue specific stability of nuclear- and mitochondrially-encoded mRNAs. Archives of Biochemistry and Biophysics 333 103-108.

Craig EE \& Hood DA 1997 Influence of aging on protein import into cardiac mitochondria. American Journal of Physiology 272 H2983-H2988.
Craig EE, Chesley A \& Hood DA 1998 Thyroid hormone modifies mitochondrial phenotype by increasing protein import without altering degradation. American Journal of Physiology 275 C1508-C1515.

Dekker PJ, Martin F, Maarse AC, Bomer U, Muller H, Guiard B, Meijer M, Rassow J \& Pfanner N 1997 The Tim core complex defines the number of mitochondrial translocation contact sites and can hold arrested preproteins in the absence of matrix Hsp70Tim44. EMBO Journal 16 5408-5419.

Glass CK \& Holloway JM 1990 Biochimica et Biophysica Acta 1032 157-176.

Hachiya N, Alam R, Sakasegawa Y, Sakaguchi M, Mihara K \& Omura T 1993 A mitochondrial import factor purified from rat liver cytosol is an ATP-dependent conformational modulator for precursor proteins. EMBO Journal 12 1579-1586.

Hood DA 1990 Coordinated expression of cytochrome c oxidase subunit III and VIc mRNAs in rat tissues. Biochemical Journal 269 503-506.

Hood DA, Simoneau J-A, Kelly AM \& Pette D 1992 Effects of thyroid status on the expression of metabolic enzymes during chronic stimulation. American Journal of Physiology 263 C788-C793.

Iwahashi J, Yamazaki S, Komiya T, Nomura N, Nishikawa S, Endo T \& Mihara K 1997 Analysis of the functional domain of the rat liver mitochondrial import receptor Tom20. Journal of Biological Chemistry 272 18467-18472.

Jensen RE \& Kinnally KW 1997 The mitochondrial protein import pathway: are precursors imported through membrane channels? Journal of Bioenergetics and Biomembranes 29 3-10.

Kang PJ, Ostermann J, Shilling J, Neupert W, Craig EA \& Pfanner N 1990 Requirement for Hsp70 in the mitochondrial matrix for the translocation and folding of precursor proteins. Nature 348 137-143.

Komiya T, Sakaguchi M \& Mihara K 1996 Cytoplasmic chaperones determine the targeting pathway of precursor proteins to mitochondria. EMBO Journal 15 399-407.

Matouschek A, Azem A, Ratliff K, Glick BS, Schmid K \& Schatz G 1997 Active unfolding of precursor proteins during mitochondrial protein import. EMBO Journal 16 6727-6736.

Michikawa Y, Baba T, Arai Y, Sakakura T \& Kusakabe M 1993 Structure and organization of the gene encoding a mouse mitochondrial stress-70 protein. FEBS Letters 336 27-33.

Nelson BD, Luciakova K, Li R \& Betina S 1995 The role of thyroid hormone and promoter diversity in the regulation of nuclear encoded mitochondrial proteins. Biochimica et Biophysica Acta 1271 85-91.

Nishiki K, Erecinska M, Wilson DF \& Cooper S 1978 Evaluation of oxidative phosphorylation in hearts from euthyroid, hypothyroid, and hyperthyroid rats. American Journal of Physiology 235 C212-C219.

Ornatsky OI, Connor MK \& Hood DA 1995 Expression of stress proteins and mitochondrial chaperonins in chronically stimulated skeletal muscle. Biochemical Journal 311 119-123.

Paradies G, Ruggiero FM, Petrosillo G \& Quagliariello E 1994 Enhanced cytochrome oxidase activity and modification of lipids in heart mitochondria from hyperthyroid rats. Biochimica et Biophysica Acta 1225 165-170.

Peralta D, Lithgow T, Hoogenraad NJ \& Høj PB 1993 Prechaperonin 60 and preornithine trancarbamylase share components of the import apparatus but have distinct maturation pathways in rat liver mitochondria. European Journal of Biochemistry 211 881-889.

Pfanner N, Craig EA \& Hönlinger A 1997 Mitochondrial preprotein translocase. Annual Review of Cell and Developmental Biology 13 $25-51$.

Schatz G 1996 The protein import system of mitochondria. Journal of Biological Chemistry 271 31763-31766.

Schneider H-C, Berthold J, Bauer MF, Dietmeier K, Guiard B, Brunner M \& Neupert W 1994 Mitochondrial hsp70/MIM44 complex facilitates protein import. Nature 371 768-774. 
Schuler MJ \& Pette D 1998 Quantification of thyroid hormone receptor isoforms, 9-cis retinoic acid receptor $\gamma$, and nuclear receptor co-repressor by reverse-transcriptase PCR in maturing and adult skeletal muscles of rat. European Journal of Biochemistry 257 607-614.

Soboll S 1993 Thyroid hormone action on mitochondrial energy transfer. Biochimica et Biophysica Acta 1144 1-16.

Stuart RA, Cyr DM \& Neupert W 1994 Hsp70 in mitochondrial biogenesis: From chaperoning nascent polypeptide chains to facilitation of protein degradation. Experientia 50 1002-1011.

Takahashi M \& Hood DA 1996 Protein import into subsarcolemmal and intermyofibrillar skeletal muscle mitochondria: differential import regulation in distinct subcellular regions. Journal of Biological Chemistry $27127285-27291$.

Takahashi M, Chesley A, Freyssenet D \& Hood DA 1998 Contractile activity-induced adaptations in the mitochondrial protein import system. American Journal of Physiology 274 C1380-C1387.

Wagner I, Arlt H, van Dyck L, Langer T \& Neupert W 1994 Molecular chaperones cooperate with PIM1 protease in the degradation of misfolded proteins in mitochondria. EMBO Journal 13 5135-5145.

Received 30 September 1999 Accepted 11 November 1999 